\title{
Effect of Culture Media and Plant Growth Regulators on Shoot Proliferation and Rooting of Internode Explants from Moroccan Native Almond (Prunus dulcis Mill.) Genotypes
}

\author{
Souhayla Kodad $\left(\mathbb{D},{ }^{1}\right.$ Reda Melhaoui ${ }^{D},{ }^{1}$ Christophe Hano, ${ }^{2}$ Mohamed Addi, ${ }^{1}$ Nargis Sahib, ${ }^{1}$ \\ Ahmed Elamrani, ${ }^{1}$ Malika Abid, ${ }^{1}$ and Aatika Mihamou ${ }^{1}$ \\ ${ }^{1}$ Laboratoire D’Amélioration des Productions Agricoles, Biotechnologie \& Environnement (LAPABE), Faculté des Sciences, \\ Université Mohammed Premier, Oujda, Morocco \\ ${ }^{2}$ Laboratoire de Biologie des Ligneux et des Grandes Cultures (LBLGC), INRAE USC1328, Université D’Orléans, \\ 21 Rue de Loigny La Bataille, F-28000 Chartres, France \\ Correspondence should be addressed to Souhayla Kodad; souhaila.kodad@gmail.com
}

Received 21 March 2021; Revised 10 April 2021; Accepted 17 April 2021; Published 29 April 2021

Academic Editor: Maria Serrano

Copyright (c) 2021 Souhayla Kodad et al. This is an open access article distributed under the Creative Commons Attribution License, which permits unrestricted use, distribution, and reproduction in any medium, provided the original work is properly cited.

\begin{abstract}
In this study, several methods have been used to facilitate shoot formation from nodal explants of local almond ecotypes known as "Beldi" grown in Eastern Morocco. Nodal segments of divers old local genotypes were cultured on various concentrations of auxin (indole-3-butyric acid (IBA)) and cytokinins (6-benzyl-aminopurine (BAP), thidiazuron (TDZ), and kinetin (KIN)) added to two different media (Murashige and Skoog (MS) and Heller medium). The results showed that TDZ was more effective than the other tested hormones for in vitro proliferation of the "Beldi" ecotype. TDZ at the concentration of $1 \mathrm{mg} / \mathrm{L}$ significantly improved the nodal shoot proliferation rate, with the highest percentage $(63.6 \% \pm 0.63)$ and number of regenerated shoots $(13 \pm 0.54)$ recorded for S1 genotype inoculated on MS medium, while the most significant rooting rate $(60.41 \% \pm 0.81)$ of proliferated shoots and number of roots per shoot $(7.3 \pm 1.36)$ were achieved for S2 genotype on $1 \mathrm{mg} / \mathrm{L}$ of IBA incorporated to a half-strength MS medium. With $80 \%$ of plantlets survival, the rooted shoots were successfully adapted to the in vivo conditions and were grown vigorously in the greenhouse without any morphological abnormalities.
\end{abstract}

\section{Introduction}

Almond \{Prunus amygdalus [syn. P. dulcis (Mill.) D.A.Webb] is a species belonging to Rosaceae family, with a genome $2 n=16$. The almond tree, native to Central Asia $[1,2]$, is one of the oldest domesticated fruit trees. It has been introduced by Phoenicians, Grecques, and Romans in different Mediterranean regions $[3,4]$, where it has adapted to various microclimates. The almond germplasm of the Mediterranean region is adapted to drought and is frequently characterized by their sensitivity to cold [5], due to its early pre-blooming, which limits the expansion of these cultivars. Almond is a very polymorphous species due to its self-incompatibility [6] and open pollination in traditional culture [7], and its seed propagation gives highly variable local genotypes creating an important genetic variability in several areas of the Mediterranean basin. According to the observations of Grasselly and Crossa-Raynaud [5], the cultivation of traditional almond trees results in the emergence of adapted ecotypes associated with specific production areas. In terms of commercial production, almond world production was 2.2 million tonnes in 2017, and the United States provides alone $46 \%$ of the total [8]. These production concerns also areas characterized by a Mediterranean climate. The main important modern growing regions are Spain, Italy, Morocco, Tunisia, Greece, and Portugal [9]. Spain, Iran, and Morocco are considered contributing to $22 \%$ of the world total production. Moreover, the world almond production for 2018-19 was around 1.28 million metric tons 
(kernel basis) and it kept increasing year on year and in 2019/ 2020 crop added up to over 1.36 million metric tons (kernel basis), which represents $7 \%$ up from the previous season and $26 \%$ above the previous 10-year average. The global almond market size is projected to reach USD 9438.4 million by 2026, from USD 7124.1 million in 2021, recording a compound annual growth rate (CAGR) of $4.8 \%$ during 2021-2026, and is expected to reach 16.7 billion by 2026 , recording a compound annual growth rate (CAGR) of $10.46 \%$ from 2021 to 2026 [10-12].

Since the early 1900s, Morocco has been an important world producer of almonds, where its most traditional production has been under low-input, dry land culture with local cultivars and in unfavorable areas mainly upstream of mountains [13]. Northeastern Morocco region is suitable for almond "Beldi" culture with cold winter time sufficient for a cold resting period and it is well adapted to high temperature and low relative humidity in summer necessary for its maturation and harvesting time. Moreover, some preliminary physicochemical results have shown the richness in tocopherol of the local almond ecotypes [14], which indicates a great potential of the "Beldi" almonds in this region. In order to enhance the production, recent plantings have incorporated more intensive cultural practices as well as new cultivars originating from Spain and France $[15,16]$. To avoid genetic erosion of "Beldi" almond ecotypes and the loss of interesting genotypes, several recent researches are focused on a serious identification of "local cultivars" based on seedling selections which represented the germplasm of the region and where a traditional culture system was evolved that minimized inputs of labour, fertilizers, and uses of additional irrigations during dry periods [17]. Moreover, many problems like the attack of the bark beetle "Scolytus Amygdali," an important pest that belongs to the Scolytidae family, which is considered as one of the most destructive insect pests in coniferous and fruit trees in both temperate and tropical climates, could occur [18]. Since, this insect was also found on fruit trees of several countries as Morocco, Tunisia, and Egypt [19], and led to the ageing and the mortality of trees and consequently caused almond genetic erosion in those countries. In vitro propagation is an alternative to overcome this kind of problem. Since tissue culture technology has been widely used for a large-scale micropropagation of commercial plants $[20,21]$, germplasm protection [22], and development of new hybrids [23], it can provide clean planting materials (virus and diseases-free) for new orchards avoiding economic losses [24-26]. Prunus species was successfully reproduced for the first time in the 1960s [27], and most research on this species was focused on the optimization of reproduction steps by using leaves explants [28], axillary buds [29], seed [30], or branch tips [20]. Nevertheless, organogenesis seems to be highly dependent on genotype and an efficient protocol for shoot formation hangs too on type of media, plants growth regulators combinations, and medium composition and culture conditions [31]. Thus, by using young shoots from Japanese plums (cv. "America") and $1.0 \mathrm{mg} \cdot \mathrm{L}^{-1} \mathrm{IAA}$, successful in vitro propagation was achieved [32], and for "Gulf ruby" cultivar grown in Woody Plant Medium (WPM) supplemented with 0.05-0.1 mg/L IBA and 0.5-1.0 mg/L BA, an effective in vitro culture system for mature stem segments was developed showing an important shoots production and a facilitated shoots elongation.

In the same way, in many sweet cherry varieties (Prunus avium), regeneration was obtained when leaves and internode slices were cultivated in woody plant medium DKW/ WPM (1:1) and Quoirin/Lepoivre (QL) medium with thidiazuron in combination with indole-3-butyric-acid. In apricot (Prunus armeniaca) cv. "Hacihaliloglu shoot induction increased in presence of cytokinin 6-benzyladenine (BA) at either $2.0 \mathrm{mg} / \mathrm{L}$ or $1 \mathrm{mg} / \mathrm{L}$ and rooting reached high efficiency on Murashige and Skoog (MS) medium supplemented with $2.0 \mathrm{mg} / \mathrm{L}$ indole-3-butyric acid (IBA). In 11 apomictic genotypes of Malus sieboldii, MS medium was found to be the best for the multiplication rate and shoot height compared to QL medium or DKW basal medium [33].

In order to protect traditional almond plantations in Eastern Morocco, and to provide farmers with "Beldi" genotypes to exploit, it is necessary to establish conservation and protection strategies and to develop an effective protocol for clonal propagation of interesting "Beldi" almond genotypes carrying the desired agronomic traits. This paper reports methods for successful micropropagation by using segment nodal proliferation of almond "Beldi" ecotype in Eastern Morocco. In addition, methods for successful rooting of the "Beldi" ecotype as well as the transfer of plantlets to potting mix for acclimatization are reported.

\section{Materials and Methods}

2.1. Plant Materials. Nodal segments of "Beldi" almond genotypes were collected from selected local old trees growing for more than 50 years in three areas in the eastern region of Morocco (Table 1). The selection of the studied genotypes was based on pomological and physicochemical characterization of several local almond genotypes.

2.2. Explants Preparation. Nodal segments (5 to $6 \mathrm{~cm}$ long) with effectively developing shoots were gathered in March 2019 from youthful parts of "Beldi" ecotypes branches growing in three different sites of eastern Morocco (Figure 1(a)). S1 genotype was collected from Rislane, S2 genotype from Ain Sefa, and S3 genotype from Bsara. The explants were kept in an icebox during their transportation to the laboratory for in vitro micropropagation. The explants were prepared by removing additional leaves and washed under running water and afterward by using $40 \%(\mathrm{v} / \mathrm{v})$ of commercial bleach solution $(\mathrm{NaOCI})$ containing $0.05 \%(\mathrm{v} / \mathrm{v})$ Tween 20 for $30 \mathrm{~min}$, explants were surface-disinfected. The shoots were dissected into nodal segments with $20 \pm 3 \mathrm{~mm}$ long (Figure 1(b)). The disinfected explants were cultured on various concentrations of IBA and cytokinins (BAP, TDZ, KIN) added to two different media: MS (Murashige and Skoog) medium [34] and Heller medium [35] (Figure 1(c)). $3 \%$ sucrose $(\mathrm{w} / \mathrm{v})$ were added to all media and then solidified by using $0.7 \%(\mathrm{w} / \mathrm{v})$ of Agar. The $\mathrm{pH}$ was fixed at 5.7 before 
TABLE 1: Geographical coordinates of "Beldi" almond three sites used for collecting plant materials in the eastern region of Morocco.

\begin{tabular}{lc}
\hline Sites & Geographical coordinates \\
\hline Rislane & $34^{\circ} 44^{\prime} 59.8^{\prime \prime} \mathrm{N}, 002^{\circ} 26^{\prime} 44.7^{\prime \prime} \mathrm{W}$ \\
Ain Sfa & $34^{\circ} 46^{\prime} 42.4^{\prime \prime} \mathrm{N}, 002^{\circ} 09^{\prime} 28.9^{\prime \prime} \mathrm{W}$ \\
Bsara & $34^{\circ} 45^{\prime} 06.2^{\prime \prime} \mathrm{N}, 002^{\circ} 13^{\prime} 53.0^{\prime \prime} \mathrm{W}$ \\
\hline
\end{tabular}

autoclaving at $120 \pm 1^{\circ} \mathrm{C}$ for $20 \mathrm{~min}$. Plant growth regulators were added to the medium prior to the adjustment of $\mathrm{pH}$ and sterilization. The experiment was conducted in three replicates with 15 explants in each replication. 45 explants were tested in total per treatment. The inoculated cultures of nodal explants were incubated at $25 \pm 2^{\circ} \mathrm{C}$ with $16 \mathrm{~h}$ photoperiod $\left(40 \mu \mathrm{mol} \cdot \mathrm{m}^{-2} \mathrm{~s}^{-1}\right)$ provided mercury fluorescent lamps. Observations were routinely noted during four weeks to identify healthy cultures from the non-growing cultures and at the same time to discard the infected ones. The numbers of shoots per explant and shoot length were recorded after 40 days of culture duration.

2.3. Rooting and Acclimatization. In this trail, the newly formed shoots were excised and utilized for in vitro induction of roots, where various concentrations of IBA ( 0 , $0.5,1$, and $1.5 \mathrm{mg} / \mathrm{L}$ ) were added to two types of culture media (half-strength MS and Heller medium). The mixture of $1: 1: 1$ perlite, sand, and soil $(\mathrm{v} / \mathrm{v} / \mathrm{v})$ was utilized for the incubation of in vitro rooted shoots after being washed in running water. To keep up relative humidity, the rooted plantlets were secured with plastic cups for approximately 4 weeks before being transferred to a growth chamber under 16 -photoperiod and a temperature of $25^{\circ} \mathrm{C}$. The growth room was illuminated by Mercury fluorescent lamps $(400 \mathrm{~W})$. The plants were irrigated every two-three days with water and gradually acclimatized to room temperature by progressively opening the bag until the plants will be ready to be transferred to the greenhouse. Survival rate of in vitro raised plantlets has been recorded.

2.4. Statistical Analysis. In this investigation, all the experiments were prepared in a totally randomized design with three replications. Statistical data analysis was done by using Duncan's new multiple range tests using SPSS software to discriminate differences between treatments. The analysis of variance "ANOVA" method was utilized to determine the effect of growth regulators on shoot proliferation at $p \leq 0.05$.

\section{Results}

3.1. Effect of Culture Media, BAP, and IBA on Shoot Proliferation from Selected "Beldi" Almond Explants. In the first experiment, tests were made to determine the effect of two different culture media on proliferation rate, average number, and length of shoots from nodal segments of "Beldi" almond ecotypes. In this research study, MS and Heller media were used in the presence and the absence of $\mathrm{BAP}$ at the concentration of $1 \mathrm{mg} / \mathrm{L}$, or BAP combined with IBA at the concentration of $0.5 \mathrm{mg} / \mathrm{L}$. Table 2 indicates that
MS and Heller media, as well as BAP, had a significant effect on proliferation rate, shoot number, and length. The results showed that a hormone-free Heller nutrient medium gives higher results (45.6\%) of shoot proliferation for S2 genotype compared to a hormone-free MS medium (32.43\%) noted for the same genotype. The lowest regeneration frequency (27.65\%) was obtained on a hormone-free MS medium for S3. A genotype effect was observed between the different tested genotypes since S1, S2, and S3 show different proliferation rates in the same media. Regarding the interaction between media and plant growth regulators, $1 \mathrm{mg} / \mathrm{L}$ BAP allowed for better results in both media since proliferation rate was much more enhanced (more than 1.5-fold) in MS medium than in Heller medium, and the average number of shoots was high (5 times more than without hormone), except for S2 genotype grown in MS medium, where no significant effect has been obtained on the number of shoots. By combining $0.5 \mathrm{mg} / \mathrm{L}$ of IBA to $1 \mathrm{mg} / \mathrm{L}$ of BAP, both media gave significantly greater numbers of shoots than most of the other treatments, with the exception of S1 genotype cultivated in Heller medium, since the highest number of shoot (4) was recorded only with $1 \mathrm{mg} / \mathrm{L}$ of BAP. Results revealed that in vitro shoot proliferation response increased by adding $0.5 \mathrm{mg} / \mathrm{L}$ of IBA for S2 (58.50\%) and S3 (56.9\%) inoculated in MS and Heller media, while for the other experiments the maximum shoot proliferation rates were maintained in both media supplemented with $1 \mathrm{mg} / \mathrm{L}$ of BAP. In fact, the highest regeneration frequencies $(62.5 \%$ and $56.9 \%$ ) were obtained on MS medium supplemented with $1 \mathrm{mg} / \mathrm{L}$ of BAP and $0.5 \mathrm{mg} / \mathrm{L}$ of IBA for S1 and S3 genotypes, respectively, with a production of an important number of shoots (6 and 4), respectively, with significant lengths, meanly above $1 \mathrm{~cm}$. For S2 genotype, the greatest results (61.42\%) were recorded on Heller medium with $1 \mathrm{mg} / \mathrm{L}$ of BAP and $0.5 \mathrm{mg} / \mathrm{L}$ of IBA (Table 2).

\subsection{Effect of TDZ and Kinetin on Shoot Proliferation from} Selected "Beldi" Almond Explants. To find suitable plant growth regulators for multiplication of the three studied "Beldi" almond genotypes, MS medium was supplemented with two other types of cytokinin (TDZ and KIN) tested at the concentration of $1 \mathrm{mg} / \mathrm{L}$ (Table 3). There was significantly higher number of shoots raised on $1 \mathrm{mg} / \mathrm{L}$ of TDZ compared to MS medium with $1 \mathrm{mg} / \mathrm{L}$ Kin. With TDZ, S1 genotype shows significantly greater numbers of shoots $(13 \pm 0.54)$ and most of them longer than $1.0 \mathrm{~cm}$. Moreover, the results show a significantly greater proliferation rate and number of shoots per explant with TDZ $(63.6 \pm 0.63)$ compared to KIN (43.75 \pm 0.62$)$ (Table 3$)$. No shoots reached $2 \mathrm{~cm}$ in the presence of KIN for all tested genotypes. TDZ reveals to be more effective and a powerful cytokinin for nodal shoot proliferation of almond "Beldi" ecotypes.

3.3. Elongation, Rooting, and Acclimatization. In this investigation, all obtained plantlets from tested genotypes were used as a source for rooting experiments. Thus, newly formed shoots were excised from nodal segments and transferred to hormone-free MS basal medium for 


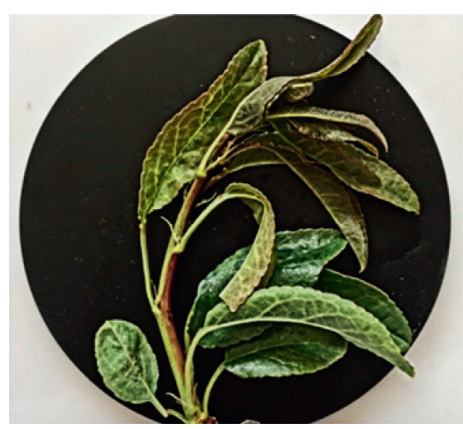

(a)

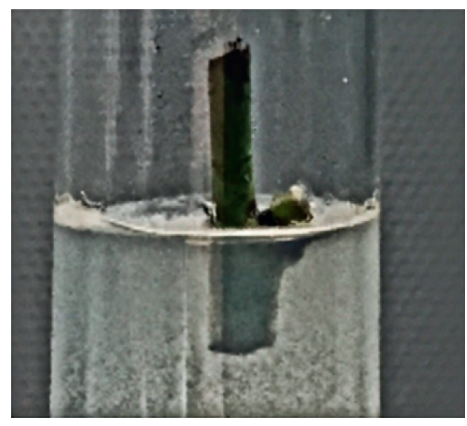

(c)

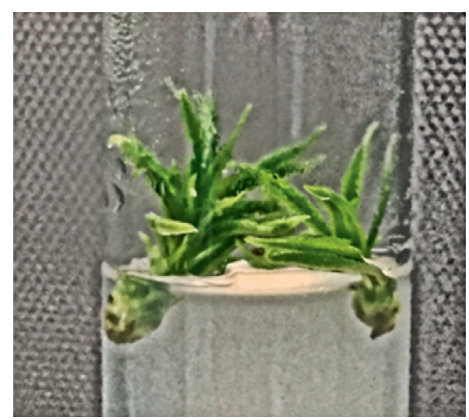

(e)

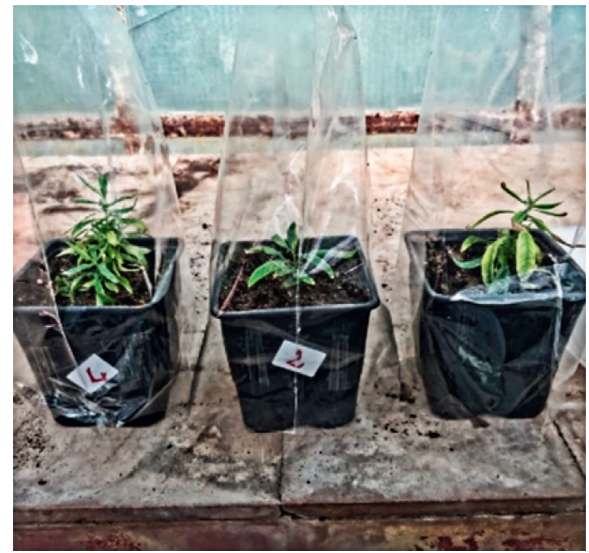

(g)

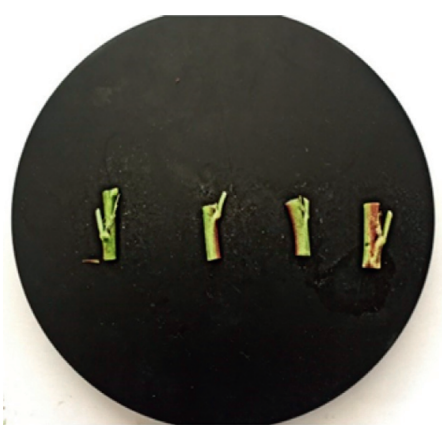

(b)

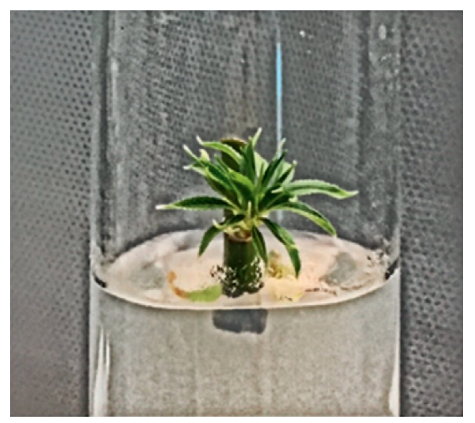

(d)

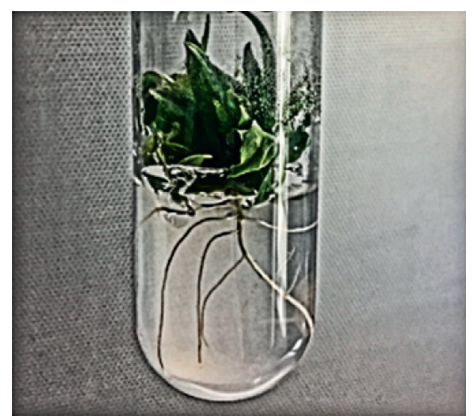

(f)

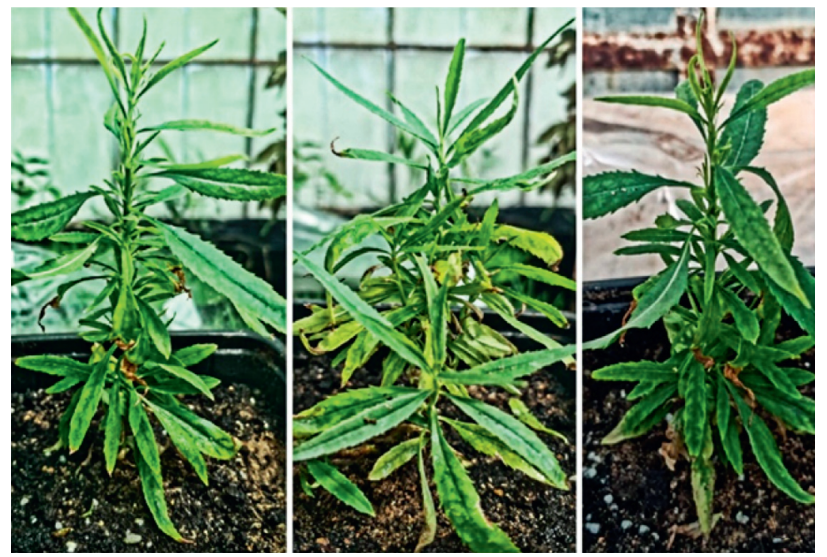

(h)

FIGURE 1: In vitro culture of nodal segments from "Beldi" almond ecotypes. (a) Young branch taken from adult almond tree. (b) 4 uninodal herbaceous cuttings. (c) Uninodal segment culture on MS medium supplemented with $1 \mathrm{mg} / \mathrm{L}$ BAP $+0.5 \mathrm{mg} / \mathrm{L}$ IBA. (d) Actively growing shoots. (e) Shoots elongation in hormone-free MS medium. (f) Formation of roots from regenerated shoot cultured on half-strength MS medium supplemented with $1 \mathrm{mg} / \mathrm{L}$ of IBA. (g) Healthy plantlets transferred to pot filled with a mixture of perlite, sand, and soil (1:1:1) after 2 weeks of acclimatization. (h) Plantlets placed in a greenhouse successfully adapted to the in vivo conditions. 
TABLE 2: Proliferation rate, average number, and length of shoots of "Beldi" almond ecotype on MS and Heller media added with 1 mg/L of BAP or IBA.

\begin{tabular}{|c|c|c|c|c|c|c|c|c|}
\hline \multirow[t]{2}{*}{ Genotype } & \multirow[t]{2}{*}{ Medium } & \multicolumn{2}{|c|}{$\begin{array}{l}\text { Plant growth } \\
\text { regulator } \\
(\mathrm{mg} / \mathrm{L})\end{array}$} & \multirow[t]{2}{*}{ Proliferation rate $(\%)$} & \multirow[t]{2}{*}{ Average number of shoots } & \multicolumn{3}{|c|}{$\begin{array}{l}\text { Average length of shoots } \\
\qquad(\mathrm{cm})\end{array}$} \\
\hline & & BAP & IBA & & & $0.4-1.0$ & $>1.0$ & $>2.0$ \\
\hline S1 & & 0 & 0 & $38.33 \pm 0.44 \mathrm{gh}$ & $1 \pm 0.46 \mathrm{~d}$ & 0 & 1 & 0 \\
\hline S2 & & 0 & 0 & $32.43 \pm 0.84 \mathrm{hi}$ & $2 \pm 0.71 \mathrm{~cd}$ & 1 & 1 & 0 \\
\hline S3 & & 0 & 0 & $27.65 \pm 0.56 \mathrm{i}$ & $1 \pm 0.04 \mathrm{~d}$ & 0 & 1 & 0 \\
\hline S1 & & 1 & 0 & $62.10 \pm 0.64 a$ & $5 \pm 1.13 \mathrm{a}$ & 2 & 2 & 1 \\
\hline S2 & MS & 1 & 0 & $47.61 \pm 1.15 \mathrm{e}$ & $2 \pm 0.58 \mathrm{~cd}$ & 0 & 2 & 0 \\
\hline S3 & & 1 & 0 & $40.65 \pm 0.76 f g$ & $3 \pm 0.62 b c$ & 0 & 2 & 1 \\
\hline S1 & & 1 & 0.5 & $62.5 \pm 0.85 a$ & $6 \pm 0.1 \mathrm{a}$ & 0 & 3 & 3 \\
\hline S2 & & 1 & 0.5 & $58.50 \pm 0.53 b$ & $5 \pm 1 b c$ & 1 & 2 & 2 \\
\hline S3 & & 1 & 0.5 & $56.9 \pm 1.46 \mathrm{bc}$ & $4 \pm 0.5 \mathrm{ab}$ & 1 & 1 & 2 \\
\hline S1 & & 0 & 0 & $37.17 \pm 0.8 \mathrm{gh}$ & $2 \pm 0.57 \mathrm{~cd}$ & 1 & 1 & 0 \\
\hline S2 & & 0 & 0 & $43.7 \pm 0.66 \mathrm{ef}$ & $1 \pm 0.17 \mathrm{~d}$ & 0 & 1 & 0 \\
\hline S3 & & 0 & 0 & $35.12 \pm 0.86 \mathrm{gh}$ & $2 \pm 0.75 c d$ & 1 & 1 & 0 \\
\hline S1 & & 1 & 0 & $60.5 \pm 0.71 \mathrm{ab}$ & $4 \pm 0.73 \mathrm{ab}$ & 1 & 2 & 1 \\
\hline S2 & Heller & 1 & 0 & $45.60 \pm 0.73 \mathrm{ef}$ & $3 \pm 0.64 b c$ & 0 & 1 & 2 \\
\hline S3 & & 1 & 0 & $41.66 \pm 0.8 \mathrm{fg}$ & $2 \pm 0.55 c d$ & 1 & 1 & 0 \\
\hline S1 & & 1 & 0.5 & $52.83 \pm 1.9 c d$ & $2 \pm 0.2 \mathrm{~cd}$ & 0 & 1 & 1 \\
\hline S2 & & 1 & 0.5 & $61.42 \pm 0.7 \mathrm{ab}$ & $4 \pm 0.1 b$ & 1 & 1 & 2 \\
\hline S3 & & 1 & 0.5 & $49.6 \pm 0.78 \mathrm{de}$ & $3 \pm 0.5 b c$ & 0 & 1 & 2 \\
\hline
\end{tabular}

Each value represents the mean \pm SE of three replicates. The same letter within a column denotes statistically equal means with Duncan's multiple range test at $p \leq 0.05$.

TABLe 3: Proliferation rate, average number, and length of "Beldi" almond ecotype shoots on MS medium in the presence of TDZ and KIN.

\begin{tabular}{|c|c|c|c|c|c|c|c|c|}
\hline \multirow[t]{2}{*}{ Genotypes } & \multirow[t]{2}{*}{ Medium } & \multicolumn{2}{|c|}{$\begin{array}{l}\text { Plant growth } \\
\text { regulators (mg/ } \\
\text { L) }\end{array}$} & & \multirow[t]{2}{*}{ Average number of shoots } & \multicolumn{3}{|c|}{$\begin{array}{l}\text { Average length of shoots } \\
\qquad(\mathrm{cm})\end{array}$} \\
\hline & & TDZ & KIN & & & $0.4-1.0$ & $>1.0$ & $>2.0$ \\
\hline S1 & MS & 1 & 0 & $63.6 \pm 0.63 a$ & $13 \pm 0.54 \mathrm{a}$ & 4 & 4 & 5 \\
\hline S2 & & 1 & 0 & $41.7 \pm 0.58 b$ & $6 \pm 0.62 \mathrm{a}$ & 1 & 3 & 2 \\
\hline S3 & & 1 & 0 & $55 \pm 0.5 a$ & $5 \pm 0.05 b c$ & 1 & 1 & 3 \\
\hline S1 & & 0 & 1 & $43.75 \pm 0.62 b$ & $3 \pm 0.33 c$ & 1 & 2 & 0 \\
\hline S2 & & 0 & 1 & $45.83 \pm 0.55 \mathrm{ab}$ & $2 \pm 0.42 c$ & 0 & 2 & 0 \\
\hline S3 & & 0 & 1 & $39.58 \pm 0.53 b$ & $4 \pm 0.13 b c$ & 1 & 3 & 0 \\
\hline
\end{tabular}

Each value represents the mean \pm SE of three replicates. The same letter within a column denotes statistically equal means with Duncan's multiple range test at $p \leq 0.05$.

elongation. Most of the studied genotypes developed in elongated shoot cultures within 2-3 weeks (Figures 1(d) and 1(e)). Well-developed shoots (around $2 \mathrm{~cm}$ ) were excised and introduced into rooting half-strength MS or Heller media containing different concentrations of IBA $(0,0.5,1$, and $1.5 \mathrm{mg} / \mathrm{L}$ ) and kept in the dark for one week. Root formation occurred as early as 2 weeks after the transfer of shoots to the rooting medium (Table 4), but the majority of the rooting occurred after 3 to 4 weeks (Figure $1(\mathrm{f})$ ). The greatest percentage of root regeneration $(60.41 \% \pm 0.81)$ was obtained when shoots were placed on half-strength MS with $1 \mathrm{mg} / \mathrm{L} \mathrm{IBA}$ and the maximum mean number of roots $(7.3 \pm 1.36)$ was regenerated for $S 2$ genotype, while for Heller medium supplemented with $1 \mathrm{mg} / \mathrm{L}$ IBA the highest percentage of rooting $(40.74 \% \pm 0.95)$ was obtained for S1 genotype and the highest mean number of roots $(6.8 \pm 1.07)$ was observed when the shoots were maintained in Heller medium supplemented with $1.5 \mathrm{mg} / \mathrm{L} \mathrm{IBA}$. The rooting response among almond "Beldi" ecotypes could also be a result of the genotype or culture conditions.

After 4 weeks, rooted plants were washed to remove agar from the roots to avoid fungal contamination and the plantlets were transferred in a 1:1:1 mixture of perlite, sand, and soil (Figure $1(\mathrm{~g})$ ). After 5 weeks of duration, the plantlets were successfully adapted to the in vivo conditions with $80 \%$ of survivability. Plants were then placed in a greenhouse where they grew vigorously without any morphological abnormalities (Figure 1(h)).

\section{Discussion}

In this study, in vitro micropropagation of nodal almond explants has been investigated in two different media and the effect of BAP, TDZ, and KIN was assessed by inoculating three main selected local almond ecotypes named "Beldi" from eastern Morocco. Nodal micro-shoots obtained from 
TABLE 4: Rooting average of the "Beldi" almond ecotypes on half-strength MS and Heller media with different concentrations of IBA.

\begin{tabular}{|c|c|c|c|c|c|}
\hline \multirow{2}{*}{ Genotypes } & \multicolumn{2}{|c|}{ Rooting media } & \multirow{2}{*}{ Rooting rate (\%) } & \multirow{2}{*}{ Root number } & \multirow{2}{*}{ Root length $(\mathrm{cm})$} \\
\hline & Media & IBA $(\mathrm{mg} / \mathrm{L})$ & & & \\
\hline & Half-strength MS & & & & \\
\hline S1 & & 0.5 & $26.08 \pm 0.75 \mathrm{e}$ & $1.4 \pm 0.10 \mathrm{f}$ & $1.0 \pm 0.10 c$ \\
\hline S2 & & 0.5 & $21.73 \pm 0.49 \mathrm{ef}$ & $3.3 \pm 1.01 \mathrm{~d}$ & $2.3 \pm 0.42 \mathrm{a}$ \\
\hline S3 & & 0.5 & $30.43 \pm 0.69 d$ & $2.1 \pm 1.07 \mathrm{e}$ & $1.7 \pm 0.44 \mathrm{ab}$ \\
\hline S1 & & 1.0 & $58.33 \pm 0.72 \mathrm{a}$ & $4.5 \pm 0.78 b c$ & $1.3 \pm 0.15 b$ \\
\hline S2 & & 1.0 & $60.41 \pm 0.81 \mathrm{a}$ & $7.3 \pm 1.36 a$ & $2.4 \pm 0.67 \mathrm{a}$ \\
\hline S3 & & 1.0 & $48.14 \pm 0.90 \mathrm{~b}$ & $6.2 \pm 1.30 \mathrm{ab}$ & $1.6 \pm 0.61 \mathrm{ab}$ \\
\hline S1 & & 1.5 & $54.16 \pm 0.52 \mathrm{ab}$ & $4.7 \pm 1.56 b$ & $1.3 \pm 0.47 \mathrm{~b}$ \\
\hline S2 & & 1.5 & $43.75 \pm 0.68 b c$ & $5.4 \pm 0.67 \mathrm{~b}$ & $1.7 \pm 1.30 \mathrm{ab}$ \\
\hline S3 & & 1.5 & $59.25 \pm 0.74 \mathrm{a}$ & $4.6 \pm 0.87 \mathrm{bc}$ & $2.1 \pm 0.59 \mathrm{a}$ \\
\hline & Heller & & & & \\
\hline S1 & & 0.5 & $15.21 \pm 0.50 \mathrm{f}$ & $1.1 \pm 0.78 \mathrm{f}$ & $0.7 \pm 0.06 c$ \\
\hline $\mathrm{S} 2$ & & 0.5 & $28.57 \pm 0.81 d$ & $2.3 \pm 0.67 \mathrm{e}$ & $0.6 \pm 0.53 c$ \\
\hline S3 & & 0.5 & $26.08 \pm 0.61 \mathrm{ef}$ & $1.5 \pm 0.53 \mathrm{f}$ & $1.4 \pm 0.67 b$ \\
\hline S1 & & 1.0 & $40.74 \pm 0.95 b c$ & $2.5 \pm 0.15 \mathrm{e}$ & $0.9 \pm 0.78 c$ \\
\hline S2 & & 1.0 & $38.09 \pm 0.59 c$ & $2.7 \pm 1.22 c$ & $1.5 \pm 0.15 b$ \\
\hline S3 & & 1.0 & $30.43 \pm 0.87 d$ & $4.8 \pm 0.76 b$ & $1.8 \pm 0.76 \mathrm{ab}$ \\
\hline S1 & & 1.5 & $21.67 \pm 0.97 \mathrm{ef}$ & $3.4 \pm 1.01 \mathrm{~d}$ & $2.2 \pm 0.63 \mathrm{a}$ \\
\hline S2 & & 1.5 & $29.26 \pm 0.90 \mathrm{~d}$ & $6.8 \pm 1.07 \mathrm{ab}$ & $1.5 \pm 0.47 \mathrm{ab}$ \\
\hline S3 & & 1.5 & $37.78 \pm 0.85 b c$ & $5.1 \pm 0.14 b$ & $1.3 \pm 0.20 \mathrm{~b}$ \\
\hline
\end{tabular}

Each value represents the mean \pm SE of three replicates. The same letter within a column denotes statistically equal means with Duncan's multiple range test at $p \leq 0.05$.

almond "Beldi" explants actively grew further to the acclimatization period and survived successfully without complications under the greenhouse conditions. This developed protocol highlighted that almond "Beldi" ecotypes could be used to preserve genetic diversity of many interesting genotypes, to establish conservation strategy, and to provide farmers with "Beldi" genotypes to exploit.

4.1. Effect of Culture Media and Plant Growth Regulators on Shoot Proliferation of Selected "Beldi" Almond Explants. In this experiment, without affecting the massive loss of explants, some contamination and browning problems of the tissues in the culture occurred (data not shown) [39]. Besides the problem of microorganisms, the release of phenolic compounds inhibited the reactivity of the explants and remains problematic in woody plants. Although the disinfection procedure of the majority of experimental Prunus protocols uses hypochlorite concentrations ranging from 5 to $15 \%$ for 10 to $20 \mathrm{~min}$ [40, 41] , in this study, $40 \%$ (v/ $\mathrm{v})$ of commercial bleach solution $(\mathrm{NaOCI})$ containing $0.05 \%$ (v/v) Tween 20 for $30 \mathrm{~min}$ has been used. This high concentration of $\mathrm{NaOCl}$ did not affect shoot regeneration but it was effective in limiting microorganism growth as the infection level decreased with the increase of contact time or $\mathrm{NaOCI}$ concentration. In addition, young branches of Beldi almond trees were taken from the current year to minimize browning. In this experiment, some contaminations and browning problems of the tissue in the culture occurred without affecting a big percentage of the explants, with a contamination rate (data not shown). Endogenous or exogenous microbiological contaminants have always limited the in vitro establishment of explants from woody plant material; in fact the proliferation of the starting plant material depends on several factors linked essentially to the physiological state of the explants but also to the nutritional and environmental conditions of the culture [42]. The losses recorded in this study are mainly due to the age of local almond trees, since the age of "Beldi" almond cultivated in eastern Morocco is estimated for more than 50 years, and this issue could be overcome by the use of a sterile cold antioxidant solution like citric acid and ascorbic acid at the time of explants rinsing or by their inclusion in the medium [43], or even by using less expensive methods such as the natural antibacterial properties of some plants, taking, for example, the infusion of olive leaves [44].

After one month of culture, a difference in shoot regeneration indicated that proliferation of starting nodal segments had depended on several factors, mainly the genotype, the type of media tested, and the plant growth regulators as well as their combinations. Although most of the nodes exhibited growth soon after the culture initiation, showing some bud swelling and leaf expansion, proliferation rate was higher in a hormone-free Heller medium $(43.7 \% \pm 0.66)$ compared to MS-free medium $(38.33 \% \pm 0.44)$ observed for S2 and S1 genotypes, respectively, while the weakest percentage of regeneration was noted for S3 genotype for both hormone-free media. Thus, shoot proliferation varied among media and genotypes tested. In general, it has been noted that S1 and S2 genotypes had a higher number and shoot proliferation rate than S3 genotype. Indeed, it is well known that regeneration frequencies are affected by the genetics of the stock. Genotypic effects were also indicated for other Prunus species $[45,46]$. Consequently, it is important to test more "Beldi" ecotypes under identical conditions to select genotypes that give the highest regeneration frequencies in in 
vitro conditions. In this research, hormone-free Heller medium was more suitable than MS medium without phytohormones for shoot proliferation of S2 and S3 genotypes. Previous studies have shown that the composition of the culture media had also an effect on shoot production. Indeed, explants cultured on MS or WP media developed significantly more shoots than explants cultured on QL medium [47]. Similar results were obtained from in vitro culture of wild cherry [48].

Growth regulators significantly improved the number of shoot proliferation. Cytokinin supplemented MS medium supported multiple shoot proliferation from the nodal explants. By adding BAP at the concentration of $1 \mathrm{mg} / \mathrm{L}, \mathrm{MS}$ medium showed higher proliferation rate $(62.10 \%$ and $47.61 \%$ ) for S1 and S2, respectively, and produced more shoots (5) for S1 genotype with significant lengths compared to those cultivated on Heller medium, while for S3 both media supplemented with $1 \mathrm{mg} / \mathrm{L}$ of BAP were optimal for inducing higher proliferation rates, while the maximum number of shoots per explant was recorded in MS medium (Table 2). Data of analysis revealed that the use of $1 \mathrm{mg} / \mathrm{L}$ of BAP supplemented to both studied media was favorable for increasing proliferation rate; mean shoots number induced per explant and mean shoot length were significantly different. This result confirms previous study reported on Prunus species when a large range of BAP was used showing high percent in promoting organogenesis for all P. Persica tested genotypes [46]. Similarly, BAP at the concentration of $2 \mathrm{mg} / \mathrm{L}$ was also proved to be best for higher number of shoot regeneration showing a maximum axillary shoot length with significant number of leaves in other plant species such as genus Morus species [49]. In this study, other BAP concentrations were not tested since it has been reported that BAP at higher concentrations decrease shoot length, and thus negatively affect shoot development [50]. Moreover, the high amounts of cytokinin in medium caused vitrification and decreased the quality and viability of the shoots [41]. The combination of BAP at $1 \mathrm{mg} / \mathrm{L}$ and IBA at $0.51 \mathrm{mg} / \mathrm{L}$ showed a significantly higher number of shoots $(6 \pm 0.1)$ and with significant lengths (more than $2 \mathrm{~cm}$ ), particularly those growing on MS medium. Those results agree with previous works on Prunus species as almond or plum where the hormone combination of IBA and BAP was most effective in both new shoot production and shoot growth rate [51-53].

In order to improve promoting shoot proliferation, it has been attempted to test TDZ and KIN effect at $1 \mathrm{mg} / \mathrm{L}$ in MS medium. Regeneration percentage was not so much affected as the number and length of shoot with TDZ. Indeed, the significant effect of TDZ was observed on higher numbers of shoots $(13 \pm 0.54)$ with significant lengths (mostly longer than $2.0 \mathrm{~cm}$ ). The same trend has also been reported in other studies, when TDZ induced high adventitious shoot numbers in many woody plant species [30, 54-57]. In this study, TDZ, a cytokinin-like chemical, was revealed to be more profitable and efficacious in promoting "Beldi" almond organogenesis. Since the most important roles of cytokinin result from its role in DNA synthesis, cell division, growth of shoots, and also the mechanism responsible for the formation of the mitotic spindle which is the regulation of protein synthesis [58], it is important to test other TDZ concentrations to increase regeneration frequencies and number of shoots regenerated for "Beldi" P. dulcis.

KIN at $1 \mathrm{mg} / \mathrm{L}$ gave the lowest results regarding shoot regeneration rate, shoot number per explant, and shoot length of the tested cytokinins. Such results were also noted for Prunus domestica where weak shoots were developed on media with KIN [51].

\subsection{Rooting and Acclimatization of Selected "Beldi" Almond} Explants. The in vitro rooting of almond microshoots was induced by different auxins, such as indole-3-butyric acid (IBA), $\alpha$-naphthaleneacetic acid (NAA), or indole-3-acetic acid (IAA) $[30,59,60]$. IBA is often tested in the root induction phase as reviewed in Dobránszki and Teixeira da Silva $[61,62]$. All the plantlets obtained in this investigation were used as a source for rooting experiments. Heller medium, which is a simple medium, usually used for rooting, was not as effective as half-strength MS medium. The highest rooting rate $(60.41 \% \pm 0.81)$ was observed for $\mathrm{S} 2$ ecotype on half MS medium strength with $1 \mathrm{mg} / \mathrm{L}$ of IBA, which was found to be the most suitable for in vitro rooting of the "Beldi" ecotypes because it also presents an important number of roots $(7.3 \pm 1.36)$ with significant lengths (up to $2.4 \pm 0.67)$. The utilization of auxins as plant hormones for in vitro induction of roots has also been reported by numerous studies for different woody species, taking, for example, Olea europaea L., Nyctanthes arbor-tristis L., Prunus avium L., and Malus pumila Mill. [63-65]. In different apple genotypes and depending on the IBA concentration used, rooting percentage varied between 18 and 100\%, with 69-74\% for axillary shoot tips [66].

In a previous study on peach rootstock Guardian, IBA plays a cardinal role in rooting, where its utilization in culture media presents the highest percentage of roots, and also contributes to a better induction of lateral roots compared to indole acetic acid (IAA) as reported by Channuntapipat, De Klerk GJ, and Ludwig-müller [67-69], successfully rooted Prunus amygdalus, batch, and the hybrid Prunus dulcis mill cv Titan x P.persica cv Nemaguard, at the same concentration after 10-21 days. Other studies on root induction experiments of the genus Prunus have shown that NAA and IAA are more effective for root stimulation than IBA $[60,70]$. Other investigations showed the highest rooting percentage $(70 \%$ and $94 \%)$ on Prunus species as compared to this study $[41,71]$. So, there are significant differences in the rate rooting depending on genotype, concentration and type of auxin, and culture conditions. Optimized in vitro rooting method can ensure successful acclimatization of almond "Beldi" ecotype. Plantlets with developed roots were transferred to pots and after 5 weeks of ex vitro growing in a greenhouse, $80 \%$ of the potted plantlets survived, and the size of the plantlets ranged between 9.5 and $14.3 \mathrm{~cm}$. $20 \%$ of the acclimatized plants were lost and this may be probably due to the fact that plants with long roots are easily damaged during transplantation [72]. In addition, the destruction of roots promotes the appearance of infected areas caused by pathogens, which can affect the survival of 
plants as it was noted for acclimatization of Japanese plum trees [32]. Moreover, the same authors emphasized that higher plant survival rate during the acclimatization period was obtained when rooting was done in presence of IAA (92\%) which gave shorter roots easier to handle during the transplant process.

In the present study, the obtained survival percentage of almond "Beldi" ecotypes (80\%) was similar to Nyctanthes arbor-tristis $\mathrm{L}$. acclimatized and transplanted into the field with $80 \%$ survival rate after 90 days [63], or almost similar to $84 \%$ reported by Espinosa et al. [41] on Prunus serotina. The acclimatized plants were successfully adapted to in vivo conditions showing that "Beldi" ecotypes can be acclimatized without any additional treatments such as paclobutrazol, cold, and $\mathrm{GA}_{3}$ treatments $[61,73,74]$ already reported for black cherry a Prunus species. Acclimatized plants were then planted in the soil where they grew vigorously without any morphological abnormalities.

\section{Conclusion}

To our knowledge, this is the first report on direct organogenesis from Almond "Beldi" ecotypes of eastern Morocco. Several almond nodal explants were used for in vitro tissue culture to assess their ability for multiplication in Murashige and Skoog (MS) medium containing different combinations of auxins and cytokinins, with $1 \mathrm{mg} / \mathrm{L}$ of BAP in combination with $0.5 \mathrm{mg} / \mathrm{L}$ IBA high proliferation rate obtained, whereas, in the presence of $1 \mathrm{mg} / \mathrm{L}$ TDZ, the highest shoot number $(13 \pm 0.54)$ longer than $2.0 \mathrm{~cm}$ was achieved, while the highest rooting rate was obtained on half-strength MS medium supplemented with $1 \mathrm{mg} / \mathrm{L}$ of IBA. This complete protocol for almond "Beldi" nodal shoot proliferation, rooting, and acclimatization could be used for the production of enormous quantities of clonal plants from aged starting material in limited space and brief timeframes. It could also be used for the preservation of selected varieties for the economic value of their characteristics or the preservation of genetic diversity.

\section{Data Availability}

All data generated or analyzed during this study are include within this article.

\section{Additional Points}

Highlights. The present study has developed a complete protocol for proliferation, rooting, and acclimatization of almond "Beldi" through nodal explants. This study could be used to preserve the genetic diversity and to conserve the interesting genotypes of almond.

\section{Conflicts of Interest}

The authors declare that they have no conflicts of interest.

\section{References}

[1] T. M. Gradziel, "Origin and dissemination of almond," Horticultural Reviews, vol. 38, pp. 23-81, 2011.

[2] M. Zeinalabedini, M. Khayam-Nekoui, V. Grigorian, T. M. Gradziel, and P. Martínez-Gómez, "The origin and dissemination of the cultivated almond as determined by nuclear and chloroplast SSR marker analysis," Scientia Horticulturae, vol. 125, no. 4, pp. 593-601, 2010.

[3] J. Felipe, "Convergence, catch-up and growth sustainability in Asia: some pitfalls," Oxford Development Studies, vol. 28, no. 1, pp. 51-69, 2000.

[4] D. E. Kester, T. M. Gradziel, and C. Grasselly, "Almonds (Prunus)," Genetic Resources of Temperate Fruit and Nut Crops, vol. 290, pp. 701-760, International Society for Horticultural Science, Leuven, Belgium, 1991.

[5] C. Grasselly, P. Crossa-Raynaud, and E. dan L'amandier, "Techniques Agricoles et Productions Méditerranéennes," Maisonneuve et Larose, Paris, France, 1980.

[6] R. Socias i Company, "Fruit tree genetics at a turning point: the almond example," Theoretical and Applied Genetics, vol. 96, no. 5, pp. 588-601, 1998.

[7] P. Spiegel-Roy, "Domestication of fruit trees," The Origin and Domestication of Cultivated Plants Developments in Agricultural and Managed Forest Ecology, Elsevier, vol. 16, pp. 201-211, , Amsterdam, Netherlands, 1986.

[8] FAOSTAT, F. A. O., Crop Statistics, 2018.

[9] R. Socias i Company and T. M. Gradziel, Almonds Botany, Production and Uses, CABI, Oxfordshire, UK, 2017.

[10] A. Bjerga, "California drought transforms global food market,” Bloomberg News, New York, NY, USA, 2014.

[11] Global Almond Market Size 2021 Details Such as Revenues, Market Share, Strategies, Growth Rate, Product \& Their Pricing by Region/country for All Major Companies Future Growth by 2026-2020.

[12] International Nut and Dried Fruit Council, INC, International Nut and Dried Fruit Council, Reus, Spain, 2020, https://www. nutfruit.org/industry\%0Ahttps://www.nutfruit.org/files/tech/ 1587539172_INC_Statistical_Yearbook_2019-2020.pdf.

[13] H. Azoulay and A. lansar, "The morphological structure of almond seedling population in Morocco," Acta Horticulturae, vol. 470, no. 470, pp. 96-100, 1998.

[14] R. Melhaoui, M. L. Fauconnier, M. Sindic et al., "Tocopherol analysis of almond oils produced in eastern Morocco," in Proceedings of the National Symposium for Applied Biological Sciences, Gembloux, Belgium, February 2018.

[15] A. Mahhou and F. G. Dennis, "The almond in Morocco," HortTechnology, vol. 2, no. 4, pp. 488-492, 1992.

[16] A. Lansari, A. F. Iezzoni, and D. E. Kester, "Morphological variation within collections of Moroccan almond clones and Mediterranean and North American cultivars," Euphytica, vol. 78, no. 1, pp. 27-41, 1994.

[17] S. Kodad, R. Melhaoui, N. Houmy et al., "Evaluation of pomological and biochemicalquality of Moroccan almond native genetic resources for conservation of biodiversity," E3S Web of Conferences, vol. 183, p. 04005, 2020.

[18] A. Benazoun, "Répartition des attaques de Ruguloscolytus amygdali Guerin (Coleoptera Scolytidae ) sur amandier dans la région de Tafraout," Revue Marocaine des Sciences Agronomiques et Vétérinaires, vol. 24, no. 1, pp. 35-44, 2004.

[19] A. Zeiri and M. Braham, "Parasitoids of the almond bark beetle scolytus amygdali in parasitoids of the almond bark beetle scolytus amygdali in Tunisia," Tunisian Journal of Plant Protection, vol. 8, no. 1, pp. 45-56, 2013. 
[20] M. Sulusoglu and A. Cavusoglu, "Micropropagation of cherry laurel (Prunus laurocerasus L)," Journal of Food Agriculture and Environment, vol. 11, pp. 576-579, 2013.

[21] P. Verma, A. K. Mathur, S. P. Jain, and A. Mathur, "In vitro conservation of twenty-three overexploited medicinal plants belonging to the Indian sub continent," The Scientific World Journal, vol. 2012, Article ID 929650, 10 pages, 2012.

[22] V. Isac, T. Coman, L. Marinescu et al., "Achievements and trends in the use of tissue culture for the mass propagation of fruit plants and germplasm preservation at the research institute for fruit growing, Pitesti, Romania," Romanian Biotechnological Letters, vol. 15, pp. 92-101, 2010.

[23] J. Squirrell, Z. Mandegaran, K. Yokoya, A. V. Roberts, and J. Mottley, "Cell lines and plants obtained after protoplast fusions of Rosa+Rosa, Rosa+Prunus and Rosa+Rubus," Euphytica, vol. 146, no. 3, pp. 223-231, 2005.

[24] S. Paunovic, D. Ruzic, T. Vujovic, S. Milenkovic, and D. Jevremovic, "In VitroProduction ofPlum pox virus- free plums by chemotherapy with ribavirin," Biotechnology \& Biotechnological Equipment, vol. 21, no. 4, pp. 417-421, 2007.

[25] R. Gella and P. Errea, "Application of in vitro therapy for ilarvirus elimination in three Prunus species," Journal of Phytopathology, vol. 146, no. 8-9, pp. 445-449, 1998.

[26] R. Scorza, A. Callahan, C. Dardick et al., "Genetic engineering of Plum pox virus resistance: 'HoneySweet' plum-from concept to product," Plant Cell, Tissue and Organ Culture (PCTOC), vol. 115, no. 1, pp. 1-12, 2013.

[27] P. Martínez-Gómez, R. Sánchez-Pérez, M. Rubio, F. Dicenta, T. M. Gradziel, and T. M. G. O. Sozzi, "Application of recent biotechnologies to Prunus tree crop genetic improvement," International Journal of Agriculture and Natural Resources, vol. 32, no. 2, pp. 55-78, 2005.

[28] C. M. Miguel, P. Druart, and M. M. Oliveira, "Shoot regeneration from adventitious buds induced on juvenile and adult almond (Prunus dulcis Mill.) explants," In Vitro Cellular \& Developmental Biology_Plant, vol. 32, no. 3, pp. 148-153, 1996.

[29] A.-S. Muna, A.-K. Ahmad, K. Mahmoud, and K. AbdulRahman, "In vitro propagation of a semi-dwarfing cherry rootstock," Plant Cell, Tissue and Organ Culture, vol. 59, no. 3, pp. 203-208, 1999.

[30] P. J. Ainsley, F. A. Hammerschlag, T. Bertozzi, G. G. Collins, and M. Sedgley, "Regeneration of almond from immature seed cotyledons," Plant Cell, Tissue and Organ Culture, vol. 67, no. 3, pp. 221-226, 2001.

[31] K. Magyar-Tábori, J. Dobránszki, J. A. Teixeira da Silva, S. M. Bulley, and I. Hudák, "The role of cytokinins in shoot organogenesis in apple," Plant Cell, Tissue and Organ Culture (PCTOC), vol. 101, no. 3, pp. 251-267, 2010.

[32] J. d. M. Bandeira, L. B. Thurow, E. J. B. Braga, J. A. Peters, and V. J. Bianchi, "Rooting and acclimatization of the Japanese plum tree, cv. América," Revista Brasileira de Fruticultura, vol. 34, no. 2, pp. 597-603, 2012.

[33] A. M. Ciccotti, C. Bisognin, I. Battocletti, A. Salvadori, M. Herdemertens, and W. Jarausch, "Micropropagation of apple proliferation-resistant apomictic Malus sieboldii genotypes," Agronomy Research, vol. 6, no. 2, pp. 445-458, 2008.

[34] T. Murashige and F. Skoog, "A revised medium for rapid growth and bio assays with tobacco tissue cultures," Physiologia Plantarum, vol. 15, no. 3, pp. 473-497, 1962.

[35] R. Heller, "Recherches sur la nutrition minérale des tissus végétaux cultivés in vitro," Faculté des Sciences de l'université de Paris, Paris, France, Theses, 1953.
[36] J. A. T. Silva, D. Kulus, X. Zhang, S. Zeng, G. Ma, and A. Piqueras, "Disinfection of explants for saffron (Crocus sativus) tissue culture," Environmental and Experimental Biology, vol. 14, no. 4, pp. 183-198, 2016.

[37] J. A. T. d. Silva, B. Winarto, J. Dobránszki, and S. Zeng, "Disinfection procedures for in vitro propagation of Anthurium," Folia Horticulturae, vol. 27, no. 1, pp. 3-14, 2015.

[38] V. C. Pence, "In vitro collecting (IVC). I. The effect of collecting method and antimicrobial agents on contamination in temperate and tropical collections," In Vitro Cellular \& Developmental Biology-Plant, vol. 41, no. 3, pp. 324-332, 2005.

[39] C. Leifert, C. E. Morris, and W. M. Waites, "Ecology of microbial saprophytes and pathogens in tissue culture and field-grown plants: reasons for contamination problems in vitro," Critical Reviews in Plant Sciences, vol. 13, no. 2, pp. 139-183, 1994.

[40] N. Yapar, U. Uysal, M. Yucesoy, N. Cakir, and A. Yuce, "Nosocomial bloodstream infections associated with Candida species in a Turkish University Hospital," Mycoses, vol. 49, no. 2, pp. 134-138, 2006.

[41] A. C. Espinosa, P. M. Pijut, and C. H. Michler, "Adventitious shoot regeneration and rooting of Prunus serotina in vitro cultures," HortScience, vol. 41, no. 1, pp. 193-201, 2006.

[42] M. N. Nas, Y. Bölek, and N. Sevgin, "Shortcut to long-distance developing of a tissue culture medium: micropropagation of mature almond cultivars as a case study," Turkish Journal of Botany, vol. 37, pp. 1134-1144, 2013.

[43] M. Modgil and M. Thakur, "In vitro culture of clonal rootstocks of apple for their commercial exploitation," in Proceedings of the VI International Symposium on Production and Establishment of Micropropagated Plants, vol. 1155, pp. 331336, San Remo, Italy, April 2015.

[44] A. Shekafandeh and M. M. Oliveira, "Effects of culture medium and mother plant condition on almond (Prunus dulcis mill.) shoot proliferation from nodal segments," Fruit, Vegetable and Cereal Science and Biotechnology, vol. 1, no. 2, pp. 3-6, 2010.

[45] N. J. Grant and N. Hammatt, "Adventitious shoot development from wild cherry (Prunus avium L.) leaves," New Forests, vol. 20, no. 3, pp. 287-295, 2000.

[46] A. Gentile, S. Monticelli, and C. Damiano, "Adventitious shoot regeneration in peach [Prunus persica (L.) Batsch]," Plant Cell Reports, vol. 20, no. 11, pp. 1011-1016, 2002.

[47] P. Andreu and J. A. Marín, "In vitro culture establishment and multiplication of the Prunus rootstock "Adesoto 101" (P. insititia $L$.) as affected by the type of propagation of the donor plant and by the culture medium composition," Scientia Horticulturae, vol. 106, no. 2, pp. 258-267, 2005.

[48] N. Hammatt and N. J. Grant, "Micropropagation of mature British wild cherry," Plant Cell, Tissue and Organ Culture, vol. 47, no. 2, pp. 103-110, 1997.

[49] G. K. Rohela, A. A. Shabnam, P. Shukla et al., "In vitro clonal propagation of PPR-1, a superior temperate mulberry variety," Indian Journal of Biotechnology, vol. 17, no. 4, pp. 619-625, 2018.

[50] A. Kalinina and D. C. W. Brown, "Micropropagation of ornamental Prunus spp. and GF305 peach, a Prunus viral indicator," Plant Cell Reports, vol. 26, no. 7, pp. 927-935, 2007.

[51] E. K. Wolella, "Surface sterilization and in vitro propagation of Prunus domestica L. cv. Stanley using axillary buds as explants," Journal of Biotech Research, vol. 8, p. 18, 2017.

[52] S. Gürel and Y. Gülșen, "The effects of different sucrose, agar and $\mathrm{pH}$ levels on in vitro shoot production of almond 
(Amygdalus communis L .)," Turkish Journal of Botany, vol. 22, no. 6, pp. 363-374, 1998.

[53] H. Yildirim, A. Onay, V. Süzerer, E. Tilkat, Y. Ozden-Tokatli, and H. dan Akdemir, "Micrografting of almond (Prunus dulcis mill.) cultivars "ferragnes" and "ferraduel"” Scientia Horticulturae, vol. 125, no. 3, pp. 361-367, 2010.

[54] B. Bhagwat and W. David Lane, "In vitro shoot regeneration from leaves of sweet cherry (Prunus avium) 'lapins' and 'sweetheart'," Plant Cell, Tissue and Organ Culture, vol. 78, no. 2, pp. 173-181, 2004.

[55] C.-Y. Lu, "The use of thidiazuron in tissue culture," In Vitro Cellular \& Developmental Biology - Plant, vol. 29, no. 2, pp. 92-96, 1993.

[56] B. San, Z. Li, Q. Hu, G. L. Reighard, and H. Luo, “Adventitious shoot regeneration from in vitro cultured leaf explants of peach rootstock Guardian is significantly enhanced by silver thiosulfate," Plant Cell, Tissue and Organ Culture (PCTOC), vol. 120, no. 2, pp. 757-765, 2015.

[57] G. K. Rohela, P. Jogam, M. Y. Mir et al., "Indirect regeneration and genetic fidelity analysis of acclimated plantlets through SCoT and ISSR markers in Morus alba L. cv. Chinese white," Biotechnology Reports, vol. 25, p. e00417, 2020.

[58] S. Govindaraju and P. Indra Arulselvi, "Effect of cytokinin combined elicitors (l-phenylalanine, salicylic acid and chitosan) on in vitro propagation, secondary metabolites and molecular characterization of medicinal herb-coleus aromaticus Benth (L)," Journal of the Saudi Society of Agricultural Sciences, vol. 17, no. 4, pp. 435-444, 2018.

[59] H. T. Hartmann, D. E. Kester, F. D. Davies, and R. L. Geneve, "Propagation methods and rootstock for the important fruit and nut species," Plant Propagation, Principles and Practices, pp. 527-565, Prentice-Hall, Englewood, NJ, USA, 1990.

[60] C. Isikalan, F. A. Akbas, S. Namli, E. Tilkat, and D. Basaran, "In vitro micropropagation of almond (Amygdalus communis L. cv. Nonpareil)," African Journal of Biotechnology, vol. 7, no. 12, 2008.

[61] J. Dobránszki and J. A. Teixeira da Silva, "Micropropagation of apple-a review," Biotechnology Advances, vol. 28, no. 4, pp. 462-488, 2010.

[62] J. A. T. Silva, D. Kulus, X. H. Zhang, S. J. Zeng, G. H. Ma, and A. Piqueras, "Disinfection of explants for saffron (Crocus sativus L.) tissue culture," Environmental and Experimental Biology, vol. 14, no. 4, pp. 183-198, 2016.

[63] A. K. Mishra, K. N. Tiwari, P. Mishra, S. K. Tiwari, S. K. Mishra, and R. Saini, "Effect of cytokinin and MS medium composition on efficient shoot proliferation of Nyctanthes arbor-tristis L. through cotyledonary node explant and evaluation of genetic fidelity and antioxidant capacity of regenerants," South African Journal of Botany, vol. 127, pp. 284-292, 2019.

[64] N. J. Grant and N. Hammatt, "Increased root and shoot production during micropropagation of cherry and apple rootstocks: effect of subculture frequency," Tree Physiology, vol. 19, no. 13, pp. 899-903, 1999.

[65] M. Bayraktar, S. Hayta-Smedley, S. Unal, N. Varol, and A. Gurel, "Micropropagation and prevention of hyperhydricity in olive (Olea europaea L.) cultivar 'Gemlik'," South African Journal of Botany, vol. 128, pp. 264-273, 2020.

[66] C. Mert and A. Soylu, "Shoot location and collection time effects on meristem tip culture of some apple rootstocks," Pakistan Journal of Botany, vol. 42, no. 1, pp. 549-557, 2010.

[67] C. Channuntapipat, M. Sedgley, and G. Collins, "Micropropagation of almond cultivars nonpareil and Ne plus ultra and the hybrid rootstock Titan $\times$ Nemaguard," Scientia Horticulturae, vol. 98, no. 4, pp. 473-484, 2003.

[68] G. J. D. Klerk, W. V. D. Krieken, and J. C. D. Jong, "Review the formation of adventitious roots: new concepts, new possibilities," In Vitro Cellular \& Developmental Biology-Plant, vol. 35, no. 3, pp. 189-199, 1999.

[69] J. Ludwig-Müller, "Indole-3-butyric acid in plant growth and development," Plant Growth Regulation, vol. 32, no. 2-3, pp. 219-230, 2000.

[70] E. Rugini and D. C. Verma, "Micropropagation of difficult-topropagate almond (Prunus amygdalus, Batsch) cultivar," Plant Science Letters, vol. 28, no. 3, pp. 273-281, 1983.

[71] D. M. Tricoli, C. A. Maynard, and A. P. Drew, "Tissue culture of propagation of mature trees of Prunus serotina Ehrh. I. Establishment, multiplication, and rooting in vitro," Forest Science, vol. 31, no. 1, pp. 201-208, 1985.

[72] E. B. Radmann, E. D. Gonçalves, and G. R. D. L. Fortes, "Concentrações de ácido indolbutírico e períodos de escuro, no enraizamento "in vitro" de amoreira-preta (Rubus sp.), cv. ébano," Revista Brasileira de Fruticultura, vol. 25, no. 1, pp. 124-126, 2003.

[73] K. L. Kavanagh, D. H. Lee, A. P. Drew, and C. A. Maynard, "The effects of GA3 and organic solvents on acclimatization of tissue culture propagated black cherry (Prunus serotina Ehrh.) plantlets," Forest Science, vol. 39, no. 4, pp. 644-654, 1993.

[74] M. K. Eliasson, C. A. Beyl, and P. A. Barker, "In vitro responses and acclimatization of Prunus serotina with paclobutrazol," Journal of Plant Growth Regulation, vol. 13, no. 3, pp. 137-142, 1994. 